\title{
ДЕЯКІ АСПЕКТИ ПРАВОВОГО РЕГУЛЮВАННЯ КАДРОВОї РОБОТИ В СУДОВІЙ СИСТЕМІ
}

\author{
ШЕВЧЕНКО АнНа Василівна - кандидат юридичних наук, суддя Київського \\ окружного адміністративного суду
}

УДК 342.9

DOI 10.32782/LAW.2020.2.4

\begin{abstract}
У статті проаналізовано правове регулювання кадрової роботи в судовій системі Украӥни. Характер сучасного правового забезпечення кадрової роботи в обумовлений наступними чинниками: судовою ребормою та посиленням громадсъкої участі у бормуванні якісного суддівсъкого корпусу; підвищенням вимог до дисииплінарної поведінки суддів; підвищенням антикорупиійних стандартів у державі щодо державних службовиів та патронатної служби.

Прослідковується модернізачія кадрової діяльності в судових органах, про що свідчить поява законодавчих норм щодо розширення кадрових процедур на етапі відбору суддів та розширенням кола суб'єктів, залучених до кадрових прочесів.

Ключові слова: правове регулювання, судова система, кадрова діяльність, суд, нормативно-правові акти.
\end{abstract}

Відповідно до стратегії реформування судоустрою, судочинства та суміжних правових інститутів на 2015-2020 роки одним із основних чинників недосконалої діяльності судової системи $є$ недосконалість кадрового планування в системі судової влади [1].

Виконання будь-яких складних завдань вимагає комплексний підхід до їх вирішення. Належна організація роботи та здійснення ефективного судочинства безпосередньо залежить від знань та професійних якостей як керівництва кожного суду, так і окремого працівника, однак вирішення порушених питань значною мірою залежить від відпо- відних законодавчих способів їх вирішення [2, с.475], тому розробка системи нормативно-правових актів, які регулюють кадрову роботу в судових органах $є$ одним із шляхів подолання кризи у судовій системі.

Поняття нормативно-правового акта, їх ієрархії, питань підготовки стало предметом дослідження таких науковців, як С.Д. Гусарєв, М.С Кельман, О.Г. Мурашин, О.В. Петришин, П.М. Рабінович, О.Ф. Скакун, О.Д. Тихомиров М.В. Цвік та інші. Адміністративно-правове регулювання суспільних відносин розглянуто в працях таких науковців, як В. Б. Авер'янов, Ю. П. Битяк, Е.В. Додін, С.В. Ківалов, Т. О. Коломоєць, В.К. Колпаков, О.В. Кузьменко, Р.С. Мельник, В.Н. Протасов, С. Г. Стеценко та інші. Дослідженню кадрового забезпечення судів були присвячені роботи К.О. Іноземцевої, О. М. Аегнюк, Г.М. Мельника, І.Д. Прошуті та інші.

Правове регулювання у сфері кадрової роботи в судовій системі здійснюється системою нормативно-правових актів, що залежно від юридичної сили поділяються на закони та підзаконні нормативно-правові акти. У законодавстві до сих пір відсутнє закріплення поняття «нормативно-правовий акт». Спроба визначення поняття «нормативно-правовий акт» була зроблена у проєкті Закону України «Про нормативно-правові акти» від 21.01.2008 №1343-1 - нормативно-правовий акт - офіційний документ, прийнятий (виданий) уповноваженим на це суб'єктом у визначених законом формі та 
порядку, який встановлює норми права для неозначеного кола осіб і розрахований на неодноразове застосування [3]. Визначення нормативно-правового акта надається науковцями: офіційний акт-волевиявлення (рішення) уповноважених суб'єктів права, що встановлює (змінює, скасовує) правові норми з метою регулювання суспільних відносин [4, с.330]; нормативно-правовий акт, прийнятий у встановленому порядку та відповідній юридичній формі письмовий документ уповноваженого суб'єкта правотворчості, яким встановлюються, змінюються чи скасовуються юридичні норми [5, с.204], юридичний документ компетентного органу держави, в якому закріплено формально визначене, загальнообов'язкове правило поведінки, що охороняється державною владою від порушень [6, с. 155] тощо.

Отже, нормативно-правовому акту притаманні наступні ознаки: закріплює, змінює, доповнює, скасовує норми права, є офіційним актом-документом, видається вповноваженими суб'єктами відповідно до певної процедури, має неперсоніфікований характер, розрахований на багаторазове використання, публікується в офіційних виданнях.

Нормативно-правовий акт - це офіційний документ, який видається вповноваженими на те державними органами або громадянським суспільством, містить, змінює або скасовує норми права в установленому законом порядку, має неперсоніфікований характер, розрахований на багаторазове використання та публікується виданнях, визнаних офіційними державою.

Розкриття питання нормативного регулювання кадрової роботи в судовій системі акцентує увагу на двох позиціях щодо розуміння розподілу системи кадрового забезпечення. Зокрема, К. М. Ржепецька систему кадрового забезпечення адміністративних судів ототожнюе 3 формуванням висококваліфікованого суддівського корпусу [7, с. 420]. 3 погляду авторського колективу підручника «Організація судових та правоохоронних органів», кадрове забезпечення судочинства полягає у доборі суддівських кадрів та $\varepsilon$ сукупністю процедур 3 добору кандидатів на посаду судді на підставі аналізу його професійних, особистісних влас- тивостей, ступеня їх відповідності вимогам, встановленим законом, і вибір найбільш підготовлених кандидатів для виконання посадових обов'язків[8, с. 137]. Протилежної точки зору дотримується О.В. Ульяновська, яка виділяє три підсистеми кадрового забезпечення: 1) кадрове забезпечення осіб, які здійснюють добір кадрів на посаду суддів; 2) кадрове забезпечення безпосередньо суддів; 3) кадрове забезпечення апарату суду [9, с. 11]. Вважаємо, приєднуючись до думки інших науковців, що не можна обмежувати кадрове забезпечення судових органів лише кадровою роботою з суддями, оскільки кадри судів не обмежуються лише суддівським корпусом, й будемо розглядати правове регулювання кадрової роботи щодо суддівського корпусу та апарату суду[10, с.130], [11, с. 77].

Суттєвим зовнішнім фактором, що впливає на формування судової системи України є членство нашої держави в міжнародних організаціях, таких як ООН і Рада Европи, ратифікація базових для цих організацій документів, тому на сьогодні зростає актуальність гармонізації законодавства України $з$ правовими системами країн Европи [12, с.23].

Міжнародні стандарти у сфері судочинства не визначають загальних вимог до системи кадрового забезпечення діяльності судів, але стосуються конкретних питань формування та функціонування суддівського корпусу: етику і поведінку суддів, їх навчання, відбір, призначення суддів та дисциплінарні питання. Зокрема, слід навести такі міжнародні нормативно-правові акти, як Бангалорські принципи поведінки суддів, Висновок № 3 (2002) Консультативної ради європейських суддів до уваги Комітету Міністрів Ради Европи щодо принципів та правил, які регулюють професійну поведінку суддів, зокрема, питання етики, несумісної поведінки та безсторонності, Европейську хартію про статус суддів, Висновок № 5 (2003) Консультативної ради європейських суддів до уваги Комітету Міністрів Ради Европи щодо права та практики призначення суддів до Европейського суду 3 прав людини та інші [13, с. 33]. Так, Европейська хартія про статус суддів (Рада Европи, 1998 р.) закріплює, що правила відбору та призначення на посаду суддів незалежним органом 


\section{Адміністративне право}

або комісією вимагають здійснення відбору на основі здатності кандидатів вільно і неупереджено оцінювати справи, які передаються на їхній розгляд, та застосовувати закон із повагою до гідності людини. Кандидату не може бути відмовлено у посаді лише на підставі статі, етнічного чи соціального походження або на підставі його філософських чи політичних поглядів, релігійних переконань [14, с. 357].

Саме тому для з'ясування питання про змістовну наповненість моделі кадрового забезпечення діяльності судів у частині, що стосується формування та функціонування суддівського корпусу, міжнародні стандарти мають бути узагальнені і у них виділено провідну ідею, яка може бути врахована при побудові вітчизняної системи кадрового забезпечення діяльності судів [15, с. 7].

Щодо національного законодавства, то питання кадрової роботи в судовій системі регламентуються Конституцією України, що має вищу юридичну силу в ієрархії нормативно-правових актів. Так, Конституція України закріплює, що суд утворюється, реорганізовується і ліквідовується законом, проєкт якого вносить до Верховної Ради України Президент України після консультацій з Вищою радою правосуддя (ст. 125); суддя обіймає посаду безстроково (ст.126); підстави для звільнення судді (ст. 126); припинення повноваження судді (ст. 126); вимоги, які висуваються до особи, яка претендує на посаду судді (ст. 127), призначення на посаду судді здійснюється Президентом України за поданням Вищої ради правосуддя в порядку, встановленому законом (ст. 128); призначення на посаду судді здійснюється за конкурсом, крім випадків, визначених законом (ст. 128); голову Верховного Суду обирає на посаду та звільняє 3 посади шляхом таємного голосування Пленум Верховного Суду в порядку, встановленому законом (ст. 128) [16].

Таким чином, у Конституції України закріплені основні положення, які знайшли подальше відображення у нормативно-правових актах, що регулюють питання кадрової роботи в судовій системі.

Базовим нормативно-правовим актом, що регулює кадрові питання добору суддів є Закон України «Про судоустрій і статус суддів» від 02.06.2016 № 1402-VIII. У ст. 69 Закону регламентується, що на посаду судді може бути призначений громадянин України, не молодший тридцяти та не старший шістдесяти п'яти років, який має вищу юридичну освіту і стаж професійної діяльності у сфері права щонайменше п'ять років, є компетентним, доброчесним та володіє державною мовою [17].

Важливою вимогою для кандидата на посаду судді $\epsilon$ наявність вікового цензу, який становить більше тридцяти років. Таким чином, на суддівські посади зараховуються особи, які проявили себе як високоморальні громадяни, мають досвід роботи у галузі права, необхідний життєвий досвід для справедливої оцінки різних спірних ситуацій під час розгляду судових справ [18, c. 123].

Ще однією умовою є граничний вік кандидата на посаду судді, який становить шістдесят п’ять років. I.E. Марочкін звертав увагу, що, вирішуючи питання максимально можливого віку кандидата на посаду судді, необхідно виходити з інтересів суспільства: у судовій системі мають працювати особи, які $б$ могли належним чином виконувати обов'язки тривалий час [19, с. 15].

Наступна вимога до кандидата у судді є стаж професійної діяльності у сфері права щонайменше п'ять років. У Законі під стажем професійної діяльності у сфері права розуміють стаж професійної діяльності особи за спеціальністю після здобуття нею вищої юридичної освіти [17]. Вища кваліфікаційна комісія України надала роз'яснення, що за змістом діяльність особи за спеціальністю у сфері права передбачає розроблення або застосування норм права і має систематичний характер, зокрема, діяльність протягом встановленого законом строку за спеціальністю: 1) у судах та органах судової влади;2) в органах прокуратури; 3) в адвокатурі; 4) у нотаріаті; 5) органах державної влади та місцевого самоврядування; 6) у Президії Національної академії наук України та галузевих академій наук, а також у наукових та науково-педагогічних установах, організаціях та їх підрозділах, які діють у галузі права;7) підприємствах, установах, організаціях, 
зокрема на керівних та адміністративних посадах, у разі якщо така діяльність або повноваження особи чи види діяльності органу, підприємства, установи, організації передбачали, зокрема, нормотворчість, правозастосування, правову допомогу, юридичне забезпечення діяльності, претензійну роботу, виконання судових рішень, юридичне представництво інтересів осіб, захист від кримінального обвинувачення [20]. 3 нашого погляду доречним було розкрити поняття «професійна діяльність у сфері права» у п. 6. ст.69, на прикладі розкриття понять «вища юридична освіта», «науковий ступінь», «стаж наукової роботи».

У результаті чергового етапу судової реформи у 2016 році були внесені зміни до статусу основних органів кадрового забезпечення судів загальної юрисдикції - Вищої ради юстиції та Вищої кваліфікаційної коміciï суддів. Зокрема, в законі України «Про внесення змін до Конституції України (щодо правосуддя)» [21] було враховано майже всі рекомендації, надані органами Ради Европи (Парламентською Асамблеєю, Комітетом Міністрів, Європейським судом 3 прав людини, Венеціанською комісією тощо) щодо провадження судової реформи в Україні, серед яких значна частина стосувалася порядку та способу формування Вищої ради юстиції (правосуддя). Було враховано рекомендації щодо: 1) необхідності створення незалежного від виконавчої та законодавчої влади органу, який відповідав би за призначення й кар'єру суддів; 2) того, що більшість членів Вищої ради юстиції (правосуддя) чи принаймні істотну їх частину повинні складати судді; 3) забезпечення обрання членів Вищої ради правосуддя, які не є суддями, серед інших видатних юристів, університетських професорів із певним стажем перебування на посаді або звичайних громадян. I лише одна рекомендація так і не була врахована - це об'єднання Вищої ради юстиції та Вищої кваліфікаційної комісії суддів в один орган [22].

Процедуру добору, заміщення вакантної посади судді відповідно до статті 70 Закону України «Про судоустрій і статус суддів» [17] здійснює Вища кваліфікаційна комісія суддів та за результатами проведеного конкурсу вносить рекомендації Вищій раді правосуддя щодо призначення кандидата на посаду судді, які надалі розглядаються останньою. На думку Ю.О. Косткіної, подібне формулювання законодавчих положень дає змогу дійти висновку про те, що кандидатуру особи, яка пройшла всі етапи конкурсного відбору на заміщення вакантної посади судді, може бути i не затверджено, адже остаточне рішення щодо призначення конкретної особи на посаду судді приймається Вищою радою правосуддя [23, с. 141].

Закон регламентує проведення кваліфікаційного оцінювання суддів Вищою кваліфікаційною комісією суддів України 3 метою визначення здатності судді (кандидата на посаду судді) здійснювати правосуддя у відповідному суді за визначеними законом критеріями, до яких належить професійна компетентність. Встановлення відповідності судді (кандидата на посаду судді) критерію професійної компетентності $\epsilon$ іспит, який проводиться шляхом складення анонімного письмового тестування та виконання практичного завдання з метою виявлення рівня знань, практичних навичок та умінь у застосуванні закону, здатності здійснювати правосуддя у відповідному суді та з відповідною спеціалізацією [17].

Отже, ще одним законодавчим актом, на якому базується кадрова робота в судовій системі, є Закон України «Про Вищу раду правосуддя», який визначає правовий статус цього органу як колегіального, незалежного конституційного органу державної влади та суддівського врядування, який діє в Україні на постійній основі для забезпечення незалежності судової влади, їі функціонування на засадах відповідальності, підзвітності перед суспільством, формування доброчесного та високопрофесійного корпусу суддів, додержання норм Конституції і законів України, а також професійної етики в діяльності суддів і прокурорів[24].

У реалізації повноважень щодо кадрового забезпечення судів Вища рада правосуддя співпрацює в основному з Вищою кваліфікаційною комісією суддів України та Президентом України.

Вища рада правосуддя взаємодіє з Президентом України щодо кадрових питань. 


\section{Адміністративне право}

Це виражається у тому, що судді призначаються на посади одразу безстроково. Так, особа може бути призначена на посаду судді за рекомендацією Вищої кваліфікаційної комісії суддів та за умови ухвалення Вищою радою правосуддя подання про призначення судді на посаду, яке надсилається Президенту України для підписання відповідного указу[25, с. 112].

Правовий статус працівників апарату суду також визначається Законом України «Про державну службу». Для ефективного здійснення судового кадрового менеджменту у сфері державної служби законодавець закріпив категорії посад державної служби та перелік посад, які до них належать. Так, у ст. 6 Закону України «Про державну службу» зазначено, що посади державної служби в державних органах поділяються на категорії залежно від порядку призначення, характеру та обсягу повноважень і необхідних для їх виконання кваліфікації та професійної компетентності державних службовців 1) категорія «A» (вищий корпус державної служби) - посади керівників апаратів Конституційного Суду України, Верховного Суду, вищих спеціалізованих судів та їх заступників; 2) категорія «Б»- посади керівників апаратів апеляційних та місцевих судів, керівників структурних підрозділів апаратів судів, їх заступників; 3) категорія «В»- інші посади державної служби, не віднесені до категорій «A» $\mathrm{i}$ «Б» [26]. Кожна посада державної служби, в тому числі і посади державних службовців судових установ, характеризується професійною компетентністю, під якою Закон «Про державну службу» встановив здатність особи в межах, визначених за посадою повноважень, застосовувати спеціальні знання, уміння та навички, виявляти відповідні моральні та ділові якості для належного виконання встановлених завдань і обов'язків, навчання, професійного та особистісного розвитку[27, с. 280].

Крім того, у статті 20 Закону України «Про державну службу» закріплені вимоги до професійної компетенції осіб, що претендують на вступ на державну службу. Зазначені вимоги складаються із загальних та спеціальних. Типовим вимогам (включаючи спеціальні), затвердженим Кабіне- том Міністрів України, повинні відповідати особи, які претендують на зайняття посад керівників апаратів Конституційного Суду України, Верховного Суду, вищих спеціалізованих судів та їх заступників. Спеціальні вимоги висуваються до осіб, які претендують на зайняття посади керівників апаратів апеляційних та місцевих судів, керівників структурних підрозділів апаратів судів, їх заступників, а також інші посади державної служби судової системи. Спеціальні вимоги визначаються суб'єктом призначення 3 урахуванням вимог спеціальних законів, що регулюють діяльність відповідного державного органу, в порядку, затвердженому центральним органом виконавчої влади, що забезпечує формування та реалізує державну політику у сфері державної служби [27, c. 280].

\section{Висновки}

Зазначається, що правове регулювання кадрової роботи здійснюється нормативноправовими актами, які за юридичною силою можна поділити на закони та підзаконні нормативно-правові акти.

Встановлено, що у законодавстві відсутня дефініція «нормативно-правового акту». Запропоновано власне визначення нормативно правового акту, відповідно до якого під нормативно-правовим актом розуміють офіційний акт документ, який видається вповноваженими на те державними органами або громадянським суспільством, містить, змінює або скасовує норми права в установленому законом порядку, має неперсоніфікований характер, розрахований на багаторазове використання та публікується у виданнях, визнаних офіційними державою.

Зазначається, що Конституція України регулює базові питання кадрової роботи в судовій системі: нормативну основу утворення, реорганізації, ліквідації судів; строки; призначення, припинення повноваження судді; вимоги, які висуваються до особи, яка претендує на посаду судді.

Визначено, що першочергове значення для правового регулювання кадрової роботи судової гілки влади має Закон України від 2 червня 2016 року № 1402-VIII «Про су- 
доустрій і статус суддів», у якому закріплюються порядок формування судів, вимоги, що висуваються до суддів.

Запропоновано внести поняття «професійна діяльність у сфері права» у п. 6. ст.69 Закону України «Про судоустрій і статус суддів», на прикладі розкриття понять «вища юридична освіта», «науковий ступінь», «стаж наукової роботи».

Зазначається, що правове регулювання кадрової роботи у судовій системі здійснюється підзаконними нормативно-правовими актами, до яких належать укази Президента України; акти Верховної Ради України; акти органів суддівського самоврядування, постанови Кабінету Міністрів України; ^окальні нормативні акти.

\section{Мiтература}

1. Стратегія реформування судоустрою, судочинства та суміжни правових інститутів на 2015-2020 роки. URL: https:// zakon2.rada.gov.ua/laws/ show/276/2015

2. Олійченко I. М. Шляхи формування та удосконалення електронного урядування в системі органів державної влади. Вісник Чернігівського державного технологічного університету. Серія «Економічні науки». 2013. № 4 (70). С. 475-482.

3. Про нормативно-правові акти: Проект Закону України від 21.01.2008 №13431. URL: http://w1.c1.rada.gov.ua/pls/zweb2/ webproc4_1?pf3511=31416

4. Скакун О. Ф. Теорія права і держави : підруч. Харків, 2009. 655 с. С.330

5. Теорія держави і права : підруч. / кол. авт. ; кер. авт. кол. канд. юрид. наук, проф. Ю.А. Ведєрніков. 3-є вид. перероб. і доп. Дніпро, 2016; 480 с. С. 204

6. Теорія держави та права : навч. посіб. / [Е. В. Білозьоров, В. П. Власенко,О. Б. Горова, А. М. Завальний, Н. В. Заяць та ін.] ; за заг. ред. С. Д. Гусарєва, О. Д. Тихомирова. К. : НАВС, Освіта України, 2017. 320 c. C. 155

7. Ржепецька К.М. Стан судових кадрів як фактор, що впливає на ефективність адміністративного судочинства. Вчені записки Таврійського національного університету ім. В.І. Вернадського. № 1. Т. 1. 2010. C. $420-425$.
8. Марочкін I.Є. Організація судових та правоохоронних органів. Харків, 2007. $528 \mathrm{c}$.

9. Ульяновська О.В. До питання про сутність якісного кадрового забезпечення судів. Митна справа. 2014. № 1. С. 8-13.

10. Пчелін В.Б. Поняття та сутність кадрів у системі кадрового забезпечення адміністративного судочинства в Україні. Право і суспільство. 2016. № 4. С. 127-132.

11. Іноземцева К.О. Кадрова політика в системі судоустрою як основа якісного правосуддя. Науковий юридичний журнал. 2019. № 8. С.76-81.

12. Назаров I. В. Судові системи країн Європейського Союзу та України: генезис та порівняння : Монографія / I. В. Назаров. Харків, 2011. 432 с.

13. Міжнародні стандарти у сфері судочинства. К.: Істина, 2010. 488 с.

14. Прокопенко Б.О. Міжнародні стандарти добору кандидатів на посаду судді. Часопис Київського університету права. 2013. № 1. С. 356-359.

15. Мельник М.Г. Зміст категорії «кадрове забезпечення» щодо діяльності судів: теоретичні підходи до визначення. Вісник вищої ради юстиції. 2011. № 2(6). С.6-13.

16. Конституція України: Закон України від 28.06.1996 № 254к/96-ВР. Відомості Верховної Ради України. 1996. № 30. ст. 141

17. Про судоустрій і статус суддів: Закон України від 02.06.2016 № 1402-VIII. Відомості Верховної Ради України. 2016. № 31. ст.545.

18. Аагнюк О.М. Правове регулювання кадрового забезпечення судів загальної юрисдикції: основні вимоги та критерії. Порівняльно-аналітичне право. 2014. № 4.C. 122-126.

19. Марочкін I.E. Добір кандидатів на посаду суддів. Інформаційний вісник Вищої кваліфікаційної комісії суддів України. 2007. № 1(2). С. 12-34.

20. Про обрахування стажу професійної діяльності у сфері права відповідно до вимог статті 69 Закону України «Про судоустрій і статус суддів» URL: https://vkksu.gov.ua/ua/ news/pro-obrachuwannia-stazu-profiesijnoidiialnosti-u-sfieri-prawa-widpowidno- 


\section{Адміністративне право}

do-wimog-statti-69-zakonu-ukraini-prosudoustrij-i-status-suddiw/

21. Про внесення змін до Конституції України (щодо правосуддя): закон України від 02.06.2016 № 1401-VIII. Відомості Верховної Ради України. 2016. № 28.Ст. 532.

22. Список рекомендацій Ради Европи щодо судової реформи і реформи прокуратури в Україні // Центр політико-правових реформ: сайт. 12.02.2014. URL: http:// pravo.org.ua/ua/news/5000- (дата звернення: 02.04.2017)

23. Косткіна Ю.О. Взаємодія Вищої ради правосуддя з органами державної влади, органами суддівського самоврядування та іншими суб'єктами права. Вісник кримінального судочинства. 2016. № 4. С. 139146.

24. Про Вищу раду правосуддя: Закон України від 21.12.2016 № 1798-VIII. Відомості Верховної Ради. 2017. № 7-8. ст. 50

25. Голобутовський Р.3. Вища Рада правосуддя як суб'єкт кадрового забезпечення судів. Право і суспільство. 2019. № 2. С. 110113.
In the article is analyzes the legal regulation of human resources management in the judicial system of Ukraine. The nature of the current legal support for staffing is due to the following factors: judicial reform and increased public participation in the formation of a quality judicial body; increasing requirements for the disciplinary behavior of judges; raising of anti-corruption standards in the state regarding the civil servants and the patronage service. The modernization of human resources in the judicial bodies is being traced, as evidenced by the emergence of legislative norms on the extension of personnel procedures at the stage of selection of judges and the expansion of the range of subjects involved in human resources processes, enhancement of the institutional capacity of the SCA in the organizational and human resources of justice.

Keywords: legal regulation, court system, human resources activity, court, regulatory acts.

26. Про державну службу: Закон України від 10.12.2015 № 889-VIII. Відомості Верховної Ради. 2016. № 4. ст.43.

27. Русанова I.О., Юревич I.В. Деякі питання судового кадрового менеджменту. Форум права. 2016. № 4. С. 277-282. 